\title{
MODEL OF FAMILY SUBJECTIVE WELL-BEING IN RURAL AND SUB URBAN FAMILIES
}

\author{
Herien Puspitawati ${ }^{1{ }^{*}}$, Ma'mun Sarma ${ }^{2}$, Tin Herawati ${ }^{1}$, Lilik Noor Yuliati ${ }^{1}$, \\ Yasmin Azizah ${ }^{3}$
}

\author{
${ }^{1}$ Department of Family and Consumer Sciences, Faculty of Human Ecology, \\ IPB University, Bogor 16680, Indonesia \\ ${ }^{2}$ Department of Management, Faculty of Economic and Management, IPB University, Bogor 16680, Indonesia \\ ${ }^{3}$ Study Program of Magister Sciences of Family and Child Development, IPB University, Bogor 16680, Indonesia
}

*)E-mail: herien_puspitawati@email.com

\begin{abstract}
Well-being of family and child can help them to deal with problems that occur in their lives. The main objectives of the study were to analyze using Structural Equation Modeling (SEM) on the examination of the effect of family characteristics and child-parents relations on family and child subjective well-being. This was a census method and a descriptive cross-sectional study design. This study was conducted on highland farmer families living in Cianjur Regency as a typical rural family and the sub-urban of Bogor City boundary as a typical sub urban family. Samples of this study amounted to 203 families consisting of 99 families with males and 104 families with females who were examined through the census method in selected primary schools. There was no significantly difference between the reports of children and mothers to the variables of child and parent relations. However, there was a significantly difference between the child's and mother's reports to the subjective well-being variable with the condition that the child reports higher in subjective well-being for both material and non-material well-being compared to his/her mother's report. The results showed that gender latent variables directly influence the latent variable of child-parent relations. Finally, the latent variable of child-parent relationship had a direct effect on the latent variable of family and children's subjective well-being for both material and non-material.
\end{abstract}

Keywords: child, family, family relations, satisfaction, subjective well-being

\section{Model Kesejahteraan Subyektif Keluarga dan Anak pada Keluarga Perdesaan dan Sub urban}

\begin{abstract}
Abstrak
Kesejahteraan yang dirasakan oleh keluarga dan anak dapat membantu keluarga untuk menghadapi permasalahan yang terjadi dalam kehidupannya. Tujuan utama dari penelitian ini adalah untuk menganalisis dengan menggunakan Structural Equation Modeling (SEM) tentang pengaruh karakteristik keluarga dan hubungan orangtua-anak terhadap kesejahteraan subjektif keluarga dan anak. Penelitian ini menggunakan desain penelitian sensus dan deskriptif cross-sectional study. Penelitian ini dilakukan pada keluarga petani yang tinggal di dataran tinggi di Kabupaten Cianjur sebagai representasi keluarga pedesaan dan perbatasan Kota Bogor sebagai keluarga sub urban. Contoh dalam penelitian ini berjumlah 203 keluarga yang terdiri dari 99 keluarga dengan anak laki-laki dan 104 keluarga dengan anak perempuan yang diteliti melalui metode sensus di sekolah dasar terpilih. Hasil penelitian menunjukkan tidak adanya perbedaan antara perspektif ibu dan anaknya tentang variabel hubungan orangtua dan anak. Namun demikian, terdapat perbedaan yang signifikan antara laporan anak dan ibu pada variabel kesejahteraan subjektif, anak melaporkan kesejahteraan subjektif yang lebih tinggi untuk dimensi kesejahteraan materi dan nonmateri. Model penelitian menunjukkan bahwa variabel laten gender secara langsung memengaruhi variabel laten hubungan anak-orang tua. Akhirnya, variabel laten dari hubungan anak-orang tua memiliki efek langsung pada variabel laten kesejahteraan subjektif keluarga dan anak baik untuk materi maupun nonmateri.
\end{abstract}

Kata kunci: anak, keluarga, kepuasan, kesejahteraan subjektif, relasi keluarga

\section{INTRODUCTION}

The purpose of forming a family is to achieve family well-being both objective and subjective. The main purpose of this paper is to examine the model of family subjective family and the factors that influence it. Changes in family life in Indonesia over the past decade have been the trend of problems in children's social problems (criminal delinquency, immorality, and free sex), cultural problems (loss of cultural 
identity), and moral degradation (lack of respect for others, dishonesty, drug used, drunkenness and suicide) and still haven't achieved the nineyear compulsory education. Furthermore, the quality of children's education such as the examination' grades are still very low in some groups of society, especially in rural areas and in low socio-economic groups (Aristin, 2016; Aroma \& Suminar, 2012; Dewi, Zukhri, Dunia, \& Erg, 2014; Sumara, Humaedi, \& Santoso, 2017; Suneki, 2012; Wulandari, 2016).The problem of gender inequality in the education is still evident. The interesting thing is male students have more drop out of school than female students (Perhati \& Susetyo, 2017; Susetyo, Hadi, \& Angraeni, 2014).

Various problems faced by Indonesian families require families to improve their well-being. Child well-being is part of family well-being. Child well-being is important to be known as a form of early identification of problems, knowing what happened and why it happened (Thompson \& Aked, 2009). Positive child welfare comes from interactions between mother and child in family life. These interactions greatly affect childrens life both in the present and the lives of children in the future (Hastuti, Syarief, Megawangi, Guharja, \& Patmonodewo, 2008).

It is strongly believed that for the success of facing the challenges of the Indonesian Nation, the key to success is by preparing the quality of Indonesia's human resources (HR) that are complete, reliable, and cultured as well as possible. The process of establishing reliable human resources starts from the family level as the smallest unit of society through the process of children's investment activities through the function of child care and socialization, child relation with parents to achieve family and children well-being (BKKBN, 1992; Landis, 1989). The strategic problem on the quality of human resources raised in this study is that family's subjective well-being is still low, which is indicated by a sense of satisfaction and happiness that are still low both by family and children.

Evidence of the low relationship between child and parents is that there are still many conflicts and violence in the family in Indonesia. It is stated that physical violence which is conducted by parents to children will create a negative impact such as weakening the child's emotional and causing behavioral problems that will influence into adulthood and influence future social relations, including influencing parent and child relationships (Irzalinda, Puspitawati, \&
Muflikhati, 2014). The experience of witnessing, hearing, experiencing violence in a family environment has negative effects on security, stability of life and child welfare (Carlson, 2000).

This study employs a structural functional theory approach that emphasizes structure, social rules, the position of patterns and roles, and family functions (Macionis, 1995; Schwartz \& Scott, 1994; Skidmore, 1979; Spencer \& Inkeles, 1982, Turner, 1986; Winton, 1995), and life total family social (McQuarrie, 1995). This Grand theory considers the family as a balanced system, homeostasis, harmony, and a sustainable system with interrelated components of the subsystem. Talcott Parsons (Klein \& White, 1996) introduces the concept of a system approach called AGIL (Adaptation; Achievement of Goals, Integration, and Latency) related to the family system. The structural functional theory describes the order and stability, underline concepts of systemic need, socialization and interdependency in social systems (Harper, 2011).

The structural functional theory considers that keystone to systemic survival and deviation from social norms and values can harm the survival of system because society shared norms and values within systems (Smith \& Hamon, 2012). The structural functional analysis can focus to the way system works or delivering expected result. Application of this theory is about adapting systems to societal; needs not about maintaining establishing status quo (Potts, Vella, Dale, \& Sipe, 2014). Eshelman (1991), Gelles (1995), Newman and Grauerholz (2002) state that a structuralfunctional approach can be implemented to examine gender roles in parents and achieve high quality and human resources to maintain the integrity of family and society. In addition, Farrington and Chertok (Boss, Doherty, LaRossa, Schumm, \& Steinmetz, 1993), Klein and White (1996), and Winton (1995) describe that the concept of homeostasis can maintain stability so that individuals can survive in the process of adaptation to their environment.

The middle-range theory use the family ecology framework that linking family and youth wellbeing (Pedersen and Revenson, 2005). The research indicates that well-functioning nuclear families provide the best environment for children (Noller \& Atkin, 2014). Moreover Merz, Consedine, Schulze, and Schuengel (2009) state that family relationships affect individual's well-being across the life course (Thomas, Liu, \& Umberson, 2017). Urie Bronfenbrenner (Bronfenbrenner, 1986; Deacon and Firebaugh, 
1988; Holman, 1983; Klein \& White, 1996; Melson, 1980; Santrock \& Yussen, 1989) recognize family ecology as a process of socialization, care and education for children.

According to Holland et al. (Kilpatrick \& Holland, 2003) the dominant ecological perspective examines human behavior in providing basic needs for families and their relationship with the environment. Ecological systems approach that are suitable for interaction in the family, especially the interaction of parents and children in cultural and socio-economic changes (Haris \& Liebert, 1992). Family is the basic unit of society, a universal environment in which humans learn to eat, walk, and speak, and obtain a sense of identity and behavior modes (Coontz, 2000).

There are two basic ways to look at parentchild relations. One is to focus on what could be labeled as "affective dynamics"-the emotional, communicative, and affiliated processes that take place between parents and children. On another level, parent-child relationships may be understood from the perspective of "investment dynamics": In the ultimate sense, the biological function of parental care is to provide food, protection, shelter, and information (e.g., teaching of social and practical skills) to children. Parental investment results in a net fitness cost to the parent and a net fitness benefit to the child (for a more technical treatment of parental investment in human families, see Sear, in press). These two levels of analysis are fully complementary: Investment dynamics underlie and motivate affective dynamics, and are the ultimate reason for their evolution. A child's motivation to maintain closeness to his or her mother, the fear, protest, and despair if the mother is not there, and the sense of comfort that arises when in the arms of a loving parent are all crafted by natural selection to ensure parental investment-both in the here and now (e.g., protection from a possible danger) and in the future (by fostering mutual affection and love) (Giudice \& Belsky, 2011).

Well-being emphasize a desirable state of happiness, health, or prosperity (Ben-Arieh \& Shimoni, 2013). Subjective well-being refers to people's evaluations of their lives-evaluations that are both affective and cognitive (Diener, 2000). The subjective well-being is characterized by feelings optimistic in life, associated with a positive attitude toward future change in economic status (Anna, Yusuf, Alisjahbana, Ghina, \& Rahma, 2019). The quality of life is the degree to which a person enjoys the important possibilities of his/her life. Possibilities result from the opportunities and limitations each person has in his/her life and reflect the interaction of personal and environmental factors.

The subjective well-being describes a person's assessment of his life which includes physical, social, and psychological welfare indicators (Puspitawati, Simanjuntak, \& Hayati, 2012). There are two components that exist in the subjective well-being, namely the cognitive component and the affective component, where this cognitive component functions as an evaluation process of life satisfaction, while the affective component is a reflection of experience related to events that occur in one's life (Rakhman, Tentama, \& Situmorang, 2018).

Happiness is an individual result of the overall quality of results and happiness is also referred to as subjective well-being (Schimmel, 2009). Individuals with a high level of subjective wellbeing will feel more confident, can establish better social relations, and show better work performance. In a stressful situation, individuals with a high level of subjective well-being can adapt and coping more effectively with these conditions so that they feel a better life (BiswasDiener, Diener, \& Tamir, 2004).

Subjective well-being is a predictor of individual quality of life because subjective well-being influences the success of individuals in various domains of life (Pavot \& Diener, 2004). Happy individuals encounter give a more positive influence compared to a negative influence to others, and asses quality of their lives to be high in relation to life satisfaction (Suldo \& Fefer, 2013). Family is one of the key factors to predict one's subjective well-being (Joronen \& Astedt-Kurki, 2005).

Well-being is even more complex with regard to children. Well-being influences children's lives in the present and the future, as the present influences shape children's development and future outcomes (Ben-Arieh \& Shimoni, 2013). Parents have an obligation to fulfill children's rights, such as the right to education, the right to protection and the right to well-being (Rakhman et al., 2018). Personality has been treated as the most powerful predictor of subjective well-being since people react differently to the same circumstances depending on their personality traits such as optimism and extroversion. Even though personality has been reported to have strong effects on subjective wellbeing, social environments such as family, school, and 
community around children can also affect their lives. There is significant country-specific variation in children's subjective well-being over family, school, and community influences. Frequency of family activities, frequency of peer activities, and neighborhood safety are most consistently related to the levels of children's subjective well-being across the countries.

Overall health status of children, represented as the rate of child mortality under 5 , is related to children's subjective well-being. Children's subjective well-being is affected by more immediate surroundings of children's lives than macro societal factors (Lee \& Yoo, 2014). Schwartz et al. (2011) found that parent-child relationship have strong association with cognitive component in subjective well-being. Child subjective well-being have positive correlation with parent-child relationship and authoritative parenting style (Shenaar-Golan \& Goldberg, 2019).

This research is different from previous studies conducted by Clair (2012) who conducted research on parent subjective well-being in Britain that use a psychological point of view and longitudinal method, Newland et al. (2014) who conducted research on subjective wellbeing for children in a rural community in Midwestern U.S, Suldo and Fefer (2013) who conducted parent-child relationships and youth well-being that use positive psychology perspective. This research asses influence of family characteristics and relations of children and parents on subjective well-being from perceived by both parents and children by survey method and cross sectional design.

Based on the discussion above, the research question is whether family characteristics and child-parent relations affect the subjective wellbeing of their families and children. This study aims to: (1) identify family characteristics, childparent relations and subjective well-being of family and children between male and female students, (2) identify differences in maternal and child reports to child-parent relations and family and child subjective well-being of material and non-material, and (3) analyze the Structural Equation Modeling (SEM) model on the effect of family characteristics and relations of child-parents on family and child subjective well-being. The Law Number 23 of 2002 states that a child is someone who is not yet 18 years old, including a child who is still in the womb. According to Pappalia and Olds (1986), it is mentioned that the phase of the child starts from pre-birth (conception to birth), infants (born to 2 years), early childhood (2 to 6 years), childhood middle-aged children (6 to 12 years), until adolescence (12 to 20 years).

\section{METHODS}

This was a census method and a descriptive cross-sectional study design that examined the conditions of family concerning family characteristics, child-parent relations to the subjective well-being of children and families. This study was conducted on highland farmer families living in Cianjur Regency as a typical rural family and the Bogor City boundary as a typical sub-urban family. These two geographic zones are expected to bring differences in culture and habits and agricultural infrastructure which results in the well-being of children and families.

West Java Province was chosen because of the low human development index (BPS, 2015). The boundary of Bogor City was chosen considering the highest number of agricultural businesses in West Java Province, Bogor Regency. Cianjur Regency was chosen because it ranks third in the largest number of agricultural businesses in the West Java Province (BPS, 2015). The data collection of this research was conducted in May-August 2016.

A census method was applied with samples of 203 families who had 99 male and 104 female children, who were identified through a census method at elementary schools. Each family includes two respondents who were a mother and a child. The mother answered the questions of family characteristics and subjective well-being of the family, whereas the child answered the questions of child-parents relations and subjective well-being of themselves.

The uniqueness of this research applied multi sources as respondents to answer the questions-- the mother and the child in every farmer family answering the same variables. Research variables are divided into four aspects, namely (1) child-parent relations based on the mother's perspective, (2) childparent relations based on the child's perspective, (3) subjective family well-being based on the mother's perspective, and (4) subjective well-being children based on the child's perspective. The multi sources method refers to parent-child relationship as a daily interaction carried out by parents and children including activities in play, joking, negotiation of conflicts, socialization of positive behavior, and family conversations that can make children 
learn about social relationships (Laible \& Thompson, 2000).

Child-parent relations related to positive parental behavior such as asking for opinions, listening to suggestions, loving, helping, and negative behaviors such as anger, shouting, ignoring, fighting, hitting / slapping, and criticizing children. Variables of child-parent relations based on the perspective of mothers and children, each of which has 13 items of questions, measured using a Likert scale (1-4), 1=Never, 2=Sometimes, 3=Quite often, 4=Often, with Cronbach's alpha amounting to 0,610 for the child-parent relation variable total mother's answer and 0,659 for the child's answer.

A subjective well-being is a well-being which shows a feeling of personal satisfaction with their family's life (Puspitasari, Puspitawati, \& Herawati, 2013). Child well-being is a quality of life felt by children. The environment and the situation in which a child is raised affects their well-being (Irzalinda et al., 2017). The subjective well-being of family and child related to the material aspect, the non-material aspect, and interpersonal relations aspect.

The uniqueness of this study is to use multisource (2 (two) respondents in a family unit as sources of information to answer the same variable). Family and child subjective well-being variables consist of 30 questions which are measured using a Likert scale (1-4), 1=not satisfied / happy / proud, $2=a$ little satisfied / happy / proud, $3=$ quite satisfied / happy / proud, 4=very happy / proud / proud with Cronbach's alpha value of 0,834 for maternal family-answer subjective well-being and 0,934 for childanswer subjective children's well-being.
The processing of data employs Statistical Package for Social Science (SPSS) version 22 and the Structural Equation Modeling (SEM) test using the LISREL version. 8.8. The analysis used is a descriptive test to see the distribution of family characteristics, childparent relations, and subjective well-being of children and families. The differences between male and female students on family characteristics, child-parent relations and the subjective well-being of children and parents were analyzed using the independent sample ttest.

The different tests between parents and child relations, subjective well-being of parents and children both material and non-material based on mother's and child's reports use pair-t test. Pearson correlation test was conducted to analyze the relationship among variables. Data are categorized based on the cut-off categorization, namely the low category $\leq 50,0$ the medium category $50,1-75,0$ and the high category $>75,0$.

\section{RESULT}

\section{Family Characteristics}

The results from Table 1 showed that the sample came from low-income families below the minimum wage of West Java Province $(82,7 \%)$, low parental education with the average length of education of fathers and mothers respectively 5,33 and 5,36 year and the average number of family members is 6 people.

Table 1 Family characteristics based on mean and category $(\mathrm{N}=203)$

\begin{tabular}{|c|c|c|c|c|c|}
\hline \multirow{2}{*}{ Variables } & \multirow{2}{*}{ Mean } & \multirow{2}{*}{ SD } & \multicolumn{3}{|c|}{ Category } \\
\hline & & & Low & Moderate & High \\
\hline \multicolumn{6}{|c|}{ Rate of Income/month (IDR) (Minimum Wages of West Java Province 1.312.355) } \\
\hline Range (IDR/month) & & & $<$ UMP & 1-3 UMP & $>3 \mathrm{UMP}$ \\
\hline Percentage of samples & $1.014,85$ & $803.098,45$ & $82,7 \%$ & $10,3 \%$ & $1,9 \%$ \\
\hline \multicolumn{6}{|c|}{ Education of father (years) } \\
\hline Range (years) & & & $<9$ & $10-12$ & 12 \\
\hline Percentage of samples & 5,33 & 2,35 & $100,0 \%$ & $0,0 \%$ & $0,0 \%$ \\
\hline \multicolumn{6}{|c|}{ Education of mother (years) } \\
\hline Range & & & $<9$ & $10-12$ & 12 \\
\hline Percentage of samples & 5,36 & 2,05 & $99,0 \%$ & $1,0 \%$ & $0,0 \%$ \\
\hline \multicolumn{6}{|c|}{ Number of family members (persons) } \\
\hline Range (persons) & & & $\leq 4$ & $5-7$ & $\geq 8$ \\
\hline Percentage of samples & 5,49 & 1,56 & $28,6 \%$ & $61,1 \%$ & 10,3 \\
\hline
\end{tabular}


Table 2 Relations of child-parents and subjective well-being of family and child based on mean and strata $(\mathrm{N}=203)$

\begin{tabular}{|c|c|c|c|c|c|}
\hline \multirow[b]{2}{*}{ Variables name } & \multirow[b]{2}{*}{ Mean } & \multirow[b]{2}{*}{ SD } & \multicolumn{3}{|c|}{ Strata } \\
\hline & & & $\begin{array}{l}\text { Low } \\
\leq 500\end{array}$ & $\begin{array}{l}\text { Moderate } \\
50,1-75,0\end{array}$ & $\begin{array}{l}\text { High } \\
>75,0\end{array}$ \\
\hline Relations of child-parents-mother report (score $0-100$ ) & 63,86 & 40,55 & $15,3 \%$ & $31,0 \%$ & $53,7 \%$ \\
\hline Relations of child-parents-child report (score $0-100$ ) & 66,66 & 14,11 & $12,8 \%$ & $59,6 \%$ & $27,6 \%$ \\
\hline Family subjective well-being-mother report (score $0-100$ ) & 77,88 & 15,13 & $2,9 \%$ & $43,8 \%$ & $53,2 \%$ \\
\hline Child subjective well-being -child report (score $0-100$ ) & 88,99 & 10,28 & $0,5 \%$ & $12,3 \%$ & $87,2 \%$ \\
\hline
\end{tabular}

The results of the study from Table 2 found that child-parent relations variable based on mother's report $(53,7 \%)$, the subjective of family well-being based on mother's report $(53,2 \%)$, and the subjective of children well-being based on child's report $(87,2 \%)$ are in the high category. Different from child-parent relations variable based on child's report $(59,6 \%)$ that in the medium category. Thus it can be stated that the variables of child-parent relations and the subjective well-being of families and children are in good conditions.

Relations of child-parents showed that maximum half of the families in a good condition indicated by warmth and support relations from parents to child indicated by asking for opinions, listening to suggestions, loving, helping, and positive behaviors such as angerless, shouting less, ignoring less, fighting less, hitting less/slappingless, and criticizing less. Then, family and child subjective wellbeing showed that more than half of the families in a good condition indicated by satisfaction regarding materials (financial, home, health) and non-materials (education, psycho-social, parent-child relations).

\section{The Difference Test based on Sex towards Research Variables}

Table 3 showed that families of male student reported that rate of income/month (Rp1.051.775,35), education of mother $(5,45$ years), and number of family members (6 persons) were better than female students. Family of female students reported that education of father $(5,47)$ were better than male student. Research results based on variables relations of child-parents on mother report showed that relation mother with their male child $(65,22 \%)$ were better than female child. Different from child-parent on child report showed that relation mother with their female child $(68,63 \%)$ were better than male child. Family subjective well-being on mother reports showed that family of male student $(78,49 \%)$ were better than that of female student.
Similarly, the results obtained from the dimensions of material $(71,19 \%)$ and nonmaterial $(85,56 \%)$ which showed that male student were better than female. Female student reported that child subjective well-being $(89,56 \%)$ were better that male student. Similar results were also found in dimensions of material $(88,10 \%)$ and non-material $(91,00 \%)$ which showed that female student were better than male. Results based on gender difference tests of students, it was identified that there was no significantly difference between the families of male and female students in terms of family characteristics and subjective family and child well-beings, except in relations between children and parents where the child's answers indicated that there were significantly differences between the answers of male and female students.

\section{The Difference Test based on the Report of Mother and Child towards Relations of Child-Parents and Subjective Well-Being}

Results based on different tests of reporters from Table 4, namely child and mother reports, it was identified that there was no significantly difference between children and parents. However, it was identified that there was significantly difference between reporters on subjective family and child well-beings, both material and non-material dimensions. It was recognized that child's reports value greater in the child well-beings both material and nonmaterial dimensions than mother's report on those well-beings.

\section{The Effect of Family Characteristics and Child-Parents Relations toward Family and Child Subjective Well-Being}

Based on the results in Figure 1 it was indicated that Chi-Square, GFI (Goodness of Fit Index) value, RMSEA (Root Mean Square Error Approximate) were 46,76; $(p=0,00) ; 0,94 ; 1,00$; and 011, it was identified that the compiled model according to Bollen (1989) can be understood to be suitable or fit with the data collected. 
Table 3 The difference test towards research variables based on sex of students $(\mathrm{N}=203)$

\begin{tabular}{|c|c|c|c|c|}
\hline \multirow[b]{2}{*}{$\begin{array}{l}\text { Variable } \\
\text { name }\end{array}$} & \multicolumn{2}{|c|}{ Mean } & \multirow[b]{2}{*}{$\begin{array}{l}\text { Differen } \\
\text { ce test } \\
\text { t-value }\end{array}$} & \multirow[b]{2}{*}{$\begin{array}{c}\mathrm{p}- \\
\text { value }\end{array}$} \\
\hline & $\begin{array}{c}\text { Male } \\
\text { studens } \\
(n=99)\end{array}$ & $\begin{array}{l}\text { Female } \\
\text { studens } \\
(n=104)\end{array}$ & & \\
\hline $\begin{array}{l}\text { Rate of } \\
\text { income/mont } \\
\text { h (IDR) }\end{array}$ & $\begin{array}{c}1.051 .7 \\
75,35\end{array}$ & $\begin{array}{c}979.690 \\
, 34\end{array}$ & 0,638 & 0,524 \\
\hline $\begin{array}{l}\text { Education of } \\
\text { father (years) }\end{array}$ & 5,18 & 5,47 & $-0,871$ & 0,385 \\
\hline $\begin{array}{l}\text { Education of } \\
\text { mother } \\
\text { (years) }\end{array}$ & 5,45 & 5,28 & 0,609 & 0,543 \\
\hline $\begin{array}{l}\text { Number of } \\
\text { family } \\
\text { members } \\
\text { (persons) }\end{array}$ & 5,57 & 5,41 & 0,695 & 0,488 \\
\hline $\begin{array}{l}\text { Relations of } \\
\text { child-parents- } \\
\text { mother report } \\
\text { (score 0- } \\
100 \text { ) }\end{array}$ & 65,22 & 62,57 & 0,463 & 0,644 \\
\hline $\begin{array}{l}\text { Relations of } \\
\text { child-parents- } \\
\text { child report } \\
\text { (score 0- } \\
100 \text { ) }\end{array}$ & 64,59 & 68,63 & $-2,057$ & $\underset{*}{0,041}$ \\
\hline $\begin{array}{l}\text { Family } \\
\text { subjective } \\
\text { well-being - } \\
\text { mother report } \\
\text { (score 0- } \\
100 \text { ) }\end{array}$ & 78,49 & 77,29 & 0,565 & 0,573 \\
\hline $\begin{array}{l}\text { Dimension of } \\
\text { material } \\
\text { (score } 0-100)\end{array}$ & 71,19 & 69,99 & 0,442 & 0,659 \\
\hline $\begin{array}{l}\text { Dimension of } \\
\text { non- material } \\
\text { (score } 0-100)\end{array}$ & 85,79 & 84,59 & 0,636 & 0,526 \\
\hline $\begin{array}{l}\text { Child } \\
\text { subjective } \\
\text { well-being - } \\
\text { child report } \\
\text { (score 0- } \\
100)\end{array}$ & 88,40 & 89,56 & $-0,796$ & 0,427 \\
\hline $\begin{array}{l}\text { Dimension of } \\
\text { material } \\
\text { (score } 0-100)\end{array}$ & 87,07 & 88,10 & $-0,566$ & 0,572 \\
\hline $\begin{array}{l}\text { Dimension of } \\
\text { non- material } \\
\text { (score } 0-100)\end{array}$ & 89,74 & 91,00 & $-0,944$ & 0,349 \\
\hline
\end{tabular}

The results in Figure 1 then, it can be break down to Table 5 as a decomposition effect showed that the gender latent variable had a direct effect on the latent variable child-parent relationship with the beta coefficient of $\beta=0,14^{*}$ $(p<0,01)$.
Table 4 The difference test based on the report of mother and child towards relations of child-parents and subjective well-being $(\mathrm{N}=203)$

\begin{tabular}{|c|c|c|c|c|}
\hline \multirow[b]{2}{*}{ Variable name } & \multicolumn{2}{|c|}{ Mean } & \multirow{2}{*}{$\begin{array}{l}\text { Differe } \\
\text { nce } \\
\text { test } \\
\text { t-value }\end{array}$} & \multirow[b]{2}{*}{$\begin{array}{c}p- \\
\text { value }\end{array}$} \\
\hline & $\begin{array}{c}\text { Mother } \\
\text { report }\end{array}$ & $\begin{array}{l}\text { Child } \\
\text { report }\end{array}$ & & \\
\hline $\begin{array}{l}\text { Relations of } \\
\text { child-parents } \\
\text { (score } 0-100 \text { ) }\end{array}$ & 63,86 & 66,66 & $-0,949$ & 0,344 \\
\hline $\begin{array}{l}\text { Subjective well- } \\
\text { being (score 0- } \\
100 \text { ) }\end{array}$ & 77,88 & 88,99 & $-9,642$ & $\underset{* *}{0,000}$ \\
\hline $\begin{array}{l}\text { Subjective well- } \\
\text { being-dimension } \\
\text { of material } \\
\text { (score } 0-100 \text { ) }\end{array}$ & 70,58 & 87,60 & $11, \overline{6}$ & $\underset{* \star}{0,000}$ \\
\hline $\begin{array}{l}\text { Subjective well- } \\
\text { being-dimension } \\
\text { of non-material } \\
\text { (score } 0-100 \text { ) }\end{array}$ & 85,18 & 90,39 & $-4,811$ & $\underset{* *}{0,000}$ \\
\hline
\end{tabular}

Furthermore, latent variable of child-parent relations directly influenced latent variable of subjective well-being of the family and child both material and non-material with the beta coefficient of $\beta=0,30^{*}(p<0,01)$.

Thus, based on SEM analysis, it can be summarized that latent variable of child-parent relations directly influenced latent variable of family and child subjective well-being both material and non-material.

Table 5 The results of decomposition effects of factors effecting family and child subjective well-being direct and indirectly $(\mathrm{N}=203)$

\begin{tabular}{cccc}
\hline \multirow{2}{*}{ Variable } & \multicolumn{3}{c}{ Total } \\
\cline { 2 - 4 } & TE & DE & IE \\
\hline
\end{tabular}

\begin{tabular}{|c|c|c|c|}
\hline \multicolumn{4}{|l|}{$\begin{array}{l}\text { Relations of child- } \\
\text { parents } \eta_{3}\end{array}$} \\
\hline $\begin{array}{l}\text { 1. Child } \\
\text { characteristics } \eta_{1}\end{array}$ & $0,14^{*}$ & $0,14^{*}$ & 0,00 \\
\hline $\begin{array}{l}\text { 2. Family } \\
\text { characteristics } \eta_{2}\end{array}$ & 0,02 & 0,02 & 0,00 \\
\hline \multicolumn{4}{|l|}{$\begin{array}{l}\text { Family and child } \\
\text { subjective well-being } \\
\eta_{4}\end{array}$} \\
\hline $\begin{array}{l}\text { 1. Child } \\
\text { characteristics } \eta_{1}\end{array}$ & 0,06 & 0,02 & 0,04 \\
\hline $\begin{array}{l}\text { 2. Family } \\
\text { characteristics } \eta_{2}\end{array}$ & 0,05 & 0,04 & 0,01 \\
\hline $\begin{array}{l}\text { 3. Relations of child- } \\
\text { parents } \eta_{3}\end{array}$ & $0,30^{*}$ & $0,30^{*}$ & 0,00 \\
\hline
\end{tabular}




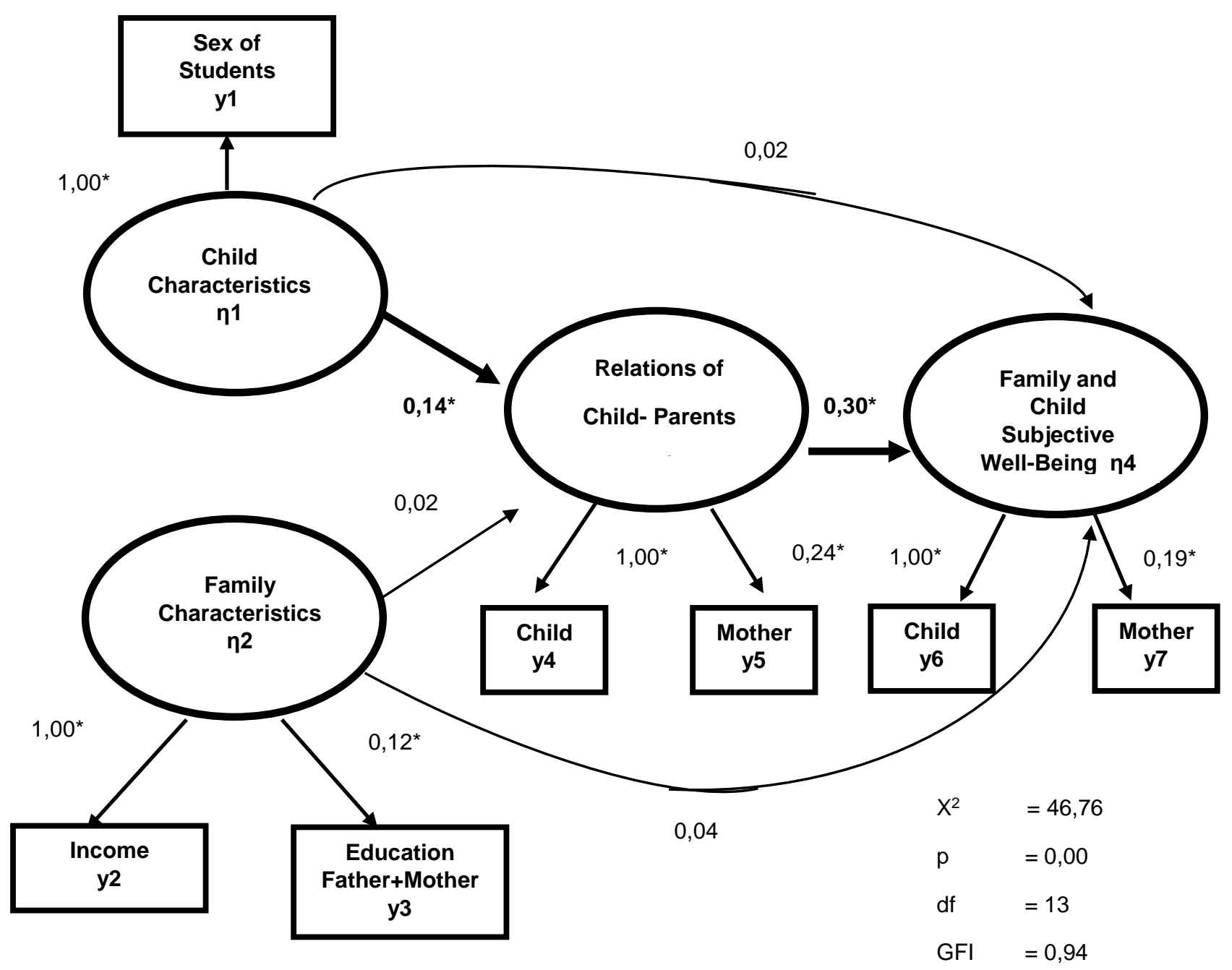

Figure 1 The effect of family characteristics and relations of child-parents toward family and child subjective well-being

\section{DISCUSSION}

The main results of Structural Equation Model analysis found that child characteristics latent variable indirectly influenced family and child subjective well-being latent variable through child-parent relations latent variable. Thus results of the research have proven the application of functional structural theory toward family life. The evidence from the results that the child-parent latent variable relationship directly influences the family and child subjective well-being latent variable both material and non-material.

As stated by Thomas et al. (2017) that family relationships play a central role in shaping an individual's well-being across the life course. This is in line with the research conducted by Clair (2012) who found that there were significantly positive relationship between parent's life satisfaction and the life satisfaction of their children. Parent's subjective well-being was compared with parent-child relationship quality in terms of influence on child life satisfaction. Parental life satisfaction measures were found to maintain their significant influence but relationship quality was found to explain a far higher amount of the variance in child life satisfaction. The quality of parent-child relationships is determined by the fulfillment of children's needs that are carried out in the form of warmth, security, trust, positive affection, and responsiveness (Bowlby, 1988). Child relations with parents can improve children's life satisfaction and respect for themselves (Armsden \& Greenberg, 1987). The quality of the relationship between parents and children is also determined by the duration of the relationship and relationships with other parties such as family, relatives, and friends (l'anah, 2017).

Based on the results of different tests of respondents' answers, there was no significantly difference between the answers of children and mothers to the variables of child and parent relations. It means that both child 
and his/her mother agree on the condition of their relations. This agreement indicated a good relation between them. A good relationship between parents and children can illustrate that children feel trust in their parents (Bretherton, 1992). Relations between good parents can support their children to explore the environment optimally, so that children's development in terms of behavior, emotions, social, cognitive and personality of children can be optimal (Nurhidayah, 2011).

Based on previous research, factors affecting child-parent relations can be described as follows. It was found that the longer mother's education was significantly and negatively associated with child parent relationship (Dewanggi, 2014). Based on research conducted by Situmorang, Hastuti, and Herawati (2016), parent-child relations are classified as low in families with low education and poor economic status. Parent-child relations living in rural areas that commonly have low social-economic status were higher than parent-child relations living in urban areas that commonly have relatively higher socialeconomic status (Dewanggi, 2014). Mother in the village is always close to the child and responds quickly to the condition of the child because the area in the village is rocky and hilly, so the mother does not let her child away from the mother's side, but still gives the child the freedom to play with friends in the neighborhood. The situation in the village which has close relations between the people, also supports the ease of children to be able to be close and feel safe with people other than mothers.

It was found in this study that there was a significantly difference between the child's and mother's response to the subjective well-being variable with the condition that the child reports was higher in subjective and material well-being compared to his mother's report. It seems that child perspectives on subjective well-being were easier to be satisfied and to be achieved than mother perspectives. As stated that family is one of the key factors to predict one's subjective well-being (Joronen \& Astedt-Kurki, 2005). Family function affect significantly positive to family subjective well-being. Families tend to be satisfied with social well-being aspects rather than the physical, psychological, and economic. It happened when the aspect of family economic function is rarely to be done. Even financial problems became more common than other issues so that the wife was not satisfied even though they are trying to manage finance in order to provide family need
(Herawati \& Endah, 2016). The subjective wellbeing of children was also influenced by receiving provisions from their family. Experience of subjective well being identified in family's provision were often related to what money could purchase such as food and shelter, instead of money itself (Hong \& Goh, 2019). In addition, the subjective well-being of children was influenced by the situation and environment in which children developed; a good environment provides appropriate support for children to develop; activities with parents and children; joint activities between parents and children that will improve child welfare and physical protection, the better physical protection provided by parents, the higher the subjective well-being of children (Irzalinda et al., 2014).

The result of gender uniqueness in children was related to child-parent relations. This was an interesting evidence that the gender aspect in child characteristics latent variable showed a direct effect on the relation of child-parent latent variable. Girls generally feel closer to parents than boys. This result relevant to the findings that girls have a higher parent-child relationship than boys (Hardani, 2017). The closeness of girls and their parents causes better communication between girls and parents compared to the communication of boys and their parents, which ties parents and children to girls (Ying et al., 2015).

Moreover, it also relevant with the findings that the higher the frequency of communication between family members, the higher the subjective well-being. Communication patterns are one component of the subjective well-being of families (Muladsih, Muflikhati, \& Herawati, 2011). Child-parent relations that are well built influence to the children to be able to get closed to people, cheerful, and loves playing with peers. These kind of children were also search for mother immediately when child is frightened or crying, and the the mother was quick to respond and within reach of children (Dewanggi, Hastuti, \& Herawati, 2015). Childparent relations will develop mental constructions on children and others so that they can build a mechanism for children's assessment of the environment (Wijirahayu, Krisnatuti, \& Muflikhati, 2016).

Limitation in this study is related to the relatively low value of Cronbach alpha's of parent-child relations based on both mother's and child's answer. This might have an effect on SEM results or overall analysis results. Furthermore, the number of farmer family as unit analysis of 
this study was also limited due to the limited population of the limited region.

\section{CONCLUSION AND SUGGESTION}

The main results of Structural Equation Model analysis found that child characteristics latent variable indirectly influenced family and child subjective well-being latent variable through child-parent relations latent variable. The results showed that gender latent variables directly influence the latent variable of childparent relations. Furthermore, the latent variable of child-parent relation had a direct effect on the latent variable of family and child subjective well-being for both material and nonmaterial.

The results also showed that the study sample derived from the low incomes families, low parental education and an average number of family members of 6 people. Furthermore, it was found that the largest proportion of the sample related to the child-parent relation variable and the family and children subjective well-being were in good condition.

Based on the results of difference tests on gender, it is indicated that there was no significantly difference between the families of male and female students in terms of family characteristics and family and child subjective well-being, except in relations between children and parents whose values were greater in children's answers than mother's answer. It was found that there was no significantly difference between the reports of children and mothers to the variables of child and parent relations. However, there was a significantly difference between the child's and mother's reports to the subjective well-being variable with the condition that the child reports higher in subjective wellbeing for both material and non-material wellbeing compared to his mother's report.

Due to the limitation of the research, it is suggested to do further research related to the test of instrument of parent-child relations based on both mother's and child's answer in a wider population. Also it is suggested to do further research related to other factors that influence subjective family well-being such as family interaction and family resilience. Research is also recommended in urban areas and coastal areas. The multimethod is also suggested to be applied in searching for data collection through multi respondents in the family. Government is suggested to empower farmer families to learn about parent-child relations and family subjective well being.

\section{REFERENCES}

[BKKBN] Badan Koordinasi Keluarga Berencana Nasional. (1992). Undangundang Republik Indonesia Nomor 10 Tahun 1992 tentang Perkembangan Kependudukan dan Pembangunan Keluarga Sejahtera. Jakarta, ID: BKKBN.

Anna, Z., Yusuf, A. A., Alisjahbana, A. S., Ghina, A. A., \& Rahma. (2019). Are fishermen happier? Evidence from a largescale subjective well-being survey in a lower-middle-income country. Marine Policy, 103559(106), 1-10. doi:10.1016/j. marpol.2019.103559.

Aristin, N. F. (2016). Faktor-faktor yang berpengaruh terhadap anak putus sekolah tingkat Sekolah Menengah Pertama (SMP) di Kecamatan Bondowoso. Jurnal Pendidikan Geografi, 20(1), 30-38.

Armsden, G. C., \& Greenberg, M. T. (1987). The inventory of parent and peer attachment: Individual differences and their relationship to psychological well-being in adolescence. Journal of Youth and Adolescence, 16(5), 427-454.doi:10.1007/ bf02202939.

Aroma, I. S., \& Suminar, D. R. (2012). Hubungan antara tingkat kontrol diri dengan kecenderungan perilaku kenakalan remaja. Jurnal Psikologi Pendidikan dan Perkembangan, 1(2), 1-6.

Ben-Arieh, A., \& Shimoni, E. (2013). Subjective well-being and perceptions of safety among Jewish and Arab children in Israel. Children and Youth Services Review, 44, 100-107. doi:https://doi.org/10.1016/j. childyouth.2014.05.017.

Biswas-Diener, R., Diener, E. D., \& Tamir, M. (2004). The psychology of subjective well being. Daedalus, 133(2), 18-25. doi:https://doi.org/10.1162/0011526043230 49352.

Bollen, K. A. (1989). Structural equations with latent variables. New York, US: John Wiley \& Sons.

Boss, P., Doherty, W. J., LaRossa, R., Schumm, W. R., \& Steinmetz, S. K. (1993). Sourcebook of family theories and methods : A contextual approach. New York, US: Plenum Press.

Bowlby, J. (1988). A secure base parent-child attachment and healthy human development. New York, US: Basic Books. 
Bretherton, I. (1992). The origins of attachment theory: John Bowlby and Mary Ainsworth. Journal of Developmental Psychology, 28(5), 758-775. doi:https://psycnet.apa .org/doi/10.1037/0012-1649.28.5.759.

Bronfenbrenner, U. (1986). Ecology of the family as a context for human development: Research perspectives. Developmental Psychology, 22(6), 723742. doi:10.1037/0012-1649.22.6.723.

Carlson, B. E. (2000). Children exposed to intimate partner violence: Research findings and implications for intervention. Trauma, Violence and Abuse, 1(4), 321340. doi:https://doi.org/10.1177\%2F152 4838000001004002.

Clair, A. (2012). The relationship between parent's subjective well-being and the life satisfaction of their children in Britain. Child Ind Res, 5(4), 631-650. doi:10.1007/s1 2187-012-9139-5.

Coontz, S. (2000). Historical perspectives on family studies. Journal of Marriage and Family, 62(2), 283-297. doi:https://doi.org/ 10.1111/j.1741-3737.2000.00283.x.

Dewanggi, M. (2014). Pengaruh kelekatan, gaya pengasuhan, dan kualitas lingkungan pengasuhan terhadap karakteristik anak perdesaan dan perkotaan (Tesis). Bogor, ID: Institut Pertanian Bogor.

Dewanggi, M., Hastuti, D., \& Herawati, T. (2015). The influence of attachment and quality of parenting and parenting environment on children's character in rural and urban areas of Bogor. Jurnal IImu Keluarga dan Konsumen, 8(1), 20-27. doi:https://doi.org/10.24156/jikk.2015.8.1.2 0 .

Dewi, N. A. K., Zukhri, A., Dunia, I. K., \& Erg, M. (2014). Analisis faktor-faktor penyebab anak putus sekolah usia pendidikan dasar di Kecamatan Gerokgak tahun 2012/2013. Jurnal Pendidikan Ekonomi Undiksha, 4(1), 1-12.

Diener, E. D. (2000). Subjective well-being the science of happiness and a proposal for a national index. American Psychologist, 55(1), 34-43. doi:10.1037//0003066X.55.1.34.

Eshelman, J. R. (1991). Family. Boston, USA: Allyn and Bacon Inc.

Gelles, R.J. (1995). Contemporary families: $A$ sociological view. London, UK: SAGE Publications.
Giudice, M. D., \& Belsky, J. (2011). Parent-child relationships: The oxford handbook of evolutionary family psychology. London, UK: Oxford University Press. doi:10.1093/ oxfordhb/9780195396690.013.0005.

Hardani, R. (2017). Pengaruh kelekatan anak dengan orangtua, guru, teman dan kontrol diri terhadap perilaku pornografi anak SMP (Tesis). Bogor, ID: Institut Pertanian Bogor.

Haris, J. C, \& Liebert, R. M. (1991). The child: A contemporary view of development. Englewood Cliffs, US: Prentice-Hall.

Harper, D. (2011). Structural-functionalism: Grand theory or methodology. Leicester, UK: University of Leicester.

Hastuti, D., Syarief, H., Megawangi, R., Guhardja, S., \& Patmonodewo, S. (2008). Karakteristik keluarga, interaksi ibu-anak, dan pengasuhan serta pengaruhnya pada tumbuh kembang anak di Bogor dan Depok. Media Gizi dan Keluarga, 32(1), 42-55.

Hong, R. T. Y., \& Goh, E. S. C. L. (2019). Using photo elicitation interviewing to access the subjective well-being of children from poor families within an affluent Asian society: Insights for service delivery. Children and Youth Service Review, 96, 430-438. doi:https://doi.org/10.1016/j.childyouth.201 8.12.006.

l'anah, N. (2017). Birr al-Walidain: Konsep relasi orang tua dan anak dalam Islam. Buletin Psikologi, 25(2), 114-123. doi:10.22146/buletinpsikologi.27302.

Irzalinda, V., Puspitawati, H., \& Muflikhati, I. (2014). Aktivitas bersama orang tua-anak dan perlindungan anak meningkatkan kesejahteraan subjektif anak. Jurnal IImu Keluarga dan Konsumen, 7(1), 40-47. doi:https://doi.org/10.24156/jikk.2014.7.1.4 0 .

Joronen, K.. \& Astedt-Kurki, P. (2005). Familial contribution to adolescent subjective wellbeing. Int $J$ Nurs Pract,11(3), 125-133. doi:https://doi.org/10.1111/j.1440172X.2005.00509.x

Kilpatrick, A. C.,\& Holland, T. P. (2003). Working with families. Boston, US: Allyn and Bacon.

Klein, D. M., \& White, J. M. (1996). Family theories: An introduction. London, UK: SAGE Publications. International Education and Professional Publisher.

Laible, D. J., \& Thompson, R. A. (2000). Mother-child discourse, attachment 
security, shared positive affect, and early conscience development. Child Development, 71(5), 1424-1440. doi:10.1111/1467-8624.00237.

Landis, J. R. (1989). Sociology: Seven education. New York, USA: Free Press.

Lee, B. J., \& Yoo, M. S. (2014). Family school and community correlates of childre's subjective well-being: An international comparative study. Child Ind Res, 8(1), 151-175. doi:10.1007/s12187-014-9285-z.

Macionis, J. J. (1995). Annotated instructor's edition sociology (5th Ed). New Jesey, US: Prentice Hall, Englewood Cliffts.

McQuarrie, D. (1995). Reading in contemporary sociological theory from modemity to postmodemity. New Jersey, US: Prentice Hall, inc.

Muladsih, O. R., Muflikhati, I., \& Herawati, T. (2011). Pola komunikasi, pengambilan keputusan, dan kesejahteraan keluarga jarak jauh: Kasus pada keluarga mahasiswa pascasarjana. Jurnal IImu Keluarga dan Konsumen, 4(2), 121-129. doi:https://doi.org/10.24156/jikk.2011.4.2.1 21.

Newland, L. A., Giger, J. T., Lawler, M. J., Carr, E. R., Dykstra, E. A., \& Roh, S. (2014). Subjective well-being for children in a rural community. Journal of Social Service Research, 40(5), 642-661. doi:10.1080/ 01488376.2014 .917450

Newman, D. M., \& Grauerholz, L. (2002). Sociology of families (2nd Ed). California, US: Pine Forge Press.

Noller, P., \& Atkin, S. (2014). Family life in adolescent. Berlin, DE: De Gruyter Open.

Nurhidayah, S. (2011). Kelekatan (attachment) dan pembentukan karakter. Turats:Jurnal Pemikiran dan Peradaban Islam, 7(2), 7883.

Pavot, W \& Diener, E. (2004). The subjective evaluation of well being in adulthood: Findings and implication. Ageing International, 29(2), 113-135.doi:10.1007/ s12126-004-1013-4.

Pedersen, S., \& Ravenson, T. A.. (2005). Parental illness, family functioning, and adolescent well-being: A family ecology framework to guide research. Journal of Family Psychology, 19(3), 404-409. doi:10.1037/0893-3200.19.3.404.

Perhati, T. A., \& Susetyo, B. (2017). Identifikasi karakteristik anak putus sekolah di Jawa
Barat dengan regresi logistik. Indonesian Journal of Statistics and Its Applications, 1(1), 56-65.

Potts, R., Vella, K., Dale, A., \& Sipe, N. (2014). Exploring the usefulness of structuralfunctional approaches to analyse governance of planning systems. Planning Theory, 15(2), 162-189. doi:10.1177/147 3095214553519.

Puspitasari, N., Puspitawati, H., \& Herawati, T. (2013). Peran gender, kontribusi ekonomi perempuan, dan kesejahteraan keluarga petani holtikultura. Jurnal IImu Keluarga dan Konsumen, 6(1), 10-19. doi:https://doi.org/10.24156/jikk.2013.6.1.1 0 .

Puspitawati, H., Simanjuntak, M., \& Hayati, L. (2012). Kontribusi ekonomi dan peran ganda perempuan serta pengaruhnya terhadap kesejahteraan subjektif. Jurnal IImu Keluarga dan Konsumen, 5(1), 11-18. doi:https://doi.org/10.24156/jikk.2012.5.1.1 1.

Rakhman, M., Tentama, F., \& Situmorang, N. Z. (2018). Gambaran subjective well-being anak perempuan pada komunitas rumah belajar Indonesia bangkit (RBOB) di Yogyakarta. Prosiding Seminar Nasional dan Call for Paper "Community Psychology". Fakultas Psikologi Universitas Muhammadiyah Jember. ISBN: 978-602-18323-2-5. pp. 1-27.

Schimmel, J. (2009). Development as happiness: The subjective perception of happiness and UNDP"s analysis of poverty, wealth and development. Journal of Happiness Studies, 10(1), 93-111. doi:10.1007\%2Fs 10902-007-9063-4.

Schwartz, M. A, \& Scott, B. M. (1994). Marriages and families: Diversity and change. New Jersey, US: Prentice-Hall Inc.

Shenaar-Golan, V., \& Goldberg, A. (2019). Subjective well-being, parent-adolescent relationship, and perceived parenting style among Israeli adolescents involved in a gap-year volunteering service. Journal of Youth Studies, 8(2), 1-15. doi:10.1080/ 13676261.2018.1563289.

Situmorang, Z. R. D., Hastuti, D., \& Herawati, T. (2016). Pengaruh kelekatan dan komunikasi dengan orang tua terhadap kerakter remaja perdesaan. Jurnal IImu Keluarga dan Konsumen, 9(2), 113-123. doi:https://doi.org/10.24156/jikk.2016.9.2.1 13. 
Skidmore, W. (1979). Theoretical thinking in sociology (2rd Ed). New York, US: Cambridge University Press.

Smith, S. R., \& Hamon, R. R. (2012). Exploring family theories (3rd Ed.). New York, US: Oxford University Press.

Spencer, M., \& Inkeles, A. (1982). Foundations of modern sociology (3rd Ed.). New Jersey, US: Prentice, Inc.

Suldo, S. M., \& Fefer, S. A. (2013). Parentchild relationships and well-being. Research, Applications, and Interventions for Children and Adolescents: A Positive Psychology Perspective, 131-147. doi:10.1007/978-94-007-6398-2_8.

Sumara, D., Humaedi, S., \& Santoso, M. (2017). Kenakalan remaja dan penanganannya. Prosiding Penelitian dan Pengabdian kepada Masyarakat, 4(2), 129-389. doi:10.24198/jppm.v4i2.14393.

Suneki, S. (2012). Dampak globalisasi terhadap eksistensi budaya daerah. CIVIS, 2(1), 115. doi:http://dx.doi.org/10.26877/civis.v 2i1/Januari.603.

Susetyo, A. B., Hadi, A. F., \& Anggraeni, D. (2014). Analisis survival data kejadian ties dengan exact partial likelihoodpadacox regression: Studi kasus data siswa putus sekolah tingkat menegah pertama. Prosiding Seminar Nasional Matematika, Universitas Jember, 1(1), 104-115.
Thomas, P. A., Liu, H., \& Umberson, D. (2017). Family relationship and well being. Innovations in Aging, 1(3), 1-11. doi:10.1093/geroni/igx025.

Thompson, S., \& Aked, J. (2009). A guide to measuring children's well-being. Retrieved from www.actionforchildren.org.uk.

Turner, J. H. (1986). The structure of sociological theory (4th Ed). Chicago, US: The Dorsey Press.

Wijirahayu, A., Krisnatuti, D., \& Muflikhati, I. (2016). Kelekatan ibu-anak, pertumbuhan anak, dan perkembangan sosial emosi anak usia prasekolah. Jurnal IImu Keluarga dan Konsumen, 9(3), 171-182. doi:https://doi.org/10.24156/jikk.2016.9.3.1 71.

Winton, C. A. (1995). Frameworks for studying families. Connecticut, USA: The Duskin Publishing Group, Inc.

Wulandari, A. (2016). Faktor-faktor penyebab anak putus sekolah di Kecamatan Senapelan Kota Pekanbaru. JOM FISIP, 3(1), 1-15.

Ying, L., Ma, F., Huang, H., Guo, X., Chen, C., \& Xu, F. (2015). Parental monitoring, parent-adolescent communication, and adolescents' trust in their parents in China. Journal PLOS ONE, 10(8), 1-9. doi:10.1371/journal.pone.0134730. 